\begin{tabular}{|c|c|c|}
\hline 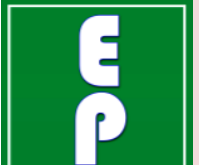 & $\begin{array}{c}\text { International Journal of Current Research } \\
\text { and Academic Review }\end{array}$ & \\
\hline $\begin{array}{l}\text { EXCELLENT } \\
\text { EXBLLISHERS }\end{array}$ & $\begin{array}{c}\text { ISSN: 2347-3215 (Online) ",; Volume 5:,; Number } 8 \text { (August-2017) } \\
\text { Journal homepage: http://www.ijcrar.com }\end{array}$ & \\
\hline
\end{tabular}

doi: https://doi.org/10.20546/ijcrar.2017.508.008

\title{
Discontinuities Study in Injana Formation in the Northeastern Limb of Pulkhana Anticline/ Northeast Iraq
}

\author{
Zakariya Qasm Jadaa* and Burkan saeed Othman
}

\author{
Kirkuk/ Iraq \\ *Corresponding author
}

\begin{abstract}
Engineering geologists study discontinuities very carefully due to their direct influence to the physiography of the landforms and fluid transportation. The study carried out in Injana Formation which is lies within Pulkhana anticline in the unstable shelf of Iraq and in an area of $5 * 10 \mathrm{~m}$, to evaluate the effects of discontinuities parameters as well as calculating stress direction that led to form discontinuities in Injana Formation. The average of each of discontinuity parameter has been taken and the orientation applied on the stereographic project (schmidth type). Measurements of discontinuities parameters showed varied readings while the main principal stresses direction that effected the study area is directed N39- 50.5E compatible with the regional stress.
\end{abstract}

\section{Article Info}

Accepted: 30 July 2017

Available Online: 20 August 2017

\section{Keywords}

Discontinuities study,

Formation,

Regional stress,

Measurements

\section{Introduction}

Discontinuity is very important in many geological studies. It control the physiography of the landforms and play an important role in the fluid transportation (Sens and Kazi, 1984; Henning et al., 2001) which is consider as a practical side of discontinuity study. Discontinuity is significantly effect on rock deformability and fluid transportation, therefore; the engineering geologists study discontinuity parameters very carefully during geological mapping, construction of civil structures, mining, tunnels, Quarry operations, power plants, nuclear- waste repositories hydrogeological applications and slope stability, (Goodman, 1976; Goodman, 1980, Hock and Bray, 1981; Plummer, 2003; Twiss \&moores, 2007; Billings, 1972). Discontinuities can reduce rock mass strength by providing weakness planes in the rock mass whereas, accumulations of stronger material at discontinuities surfaces such as quartz will increase the rock material strength (Priest and Hudson, 1976;
EdyTonnizam et al., 2005; EdyTonnizam et al., 2011). Orientation, spacing, aperture and connectivity of discontinuity have a significant importance in the groundwater flow (pollard and Aydin, 1988).Persistence, roughness and filling effect the stability of rocks (Wyllie $\&$ Mah, 2004).

As the study area is kind of virgin (i.e. there is no real human activities such as highway, railway, energy development and real building construction; therefor, the study carried out for future purposes.

The main aim of the present study is to evaluate the affection of rock discontinuities (orientation, spacing, persistence, aperture, density, frequency, roughness and filling) and identifying the common types of discontinuities (fractures) as well as calculating the stresses direction that produced these discontinuities from conjugate fractures and their relation to the regional stress. 


\section{The study area}

The study area located between latitudes ( $34^{\circ} 39^{\prime} 34.9^{\prime \prime} \mathrm{N}$ _ $\left.35^{\circ} 01^{\prime} 15.6^{\prime \prime}\right)$ and longitudes ( $44^{\circ} 31^{\prime} 52.7^{\prime \prime}$ E_ $45^{\circ} 00^{\prime}$ $57.3^{\prime \prime}$ E). The northwestern end of the study area located in Slah Al- Deen Governorate, and the southeastern end located in Diyala Governorate (Figure 1). The present study carried out in the exposed Injana Formation which was first described in Iran by Busk and Mayo in 1918 under the name of Upper Fars Formation (Bellen et al., 1959). In the study area, Injana Formation has been defined on the basis of the first major appearance of sandstone bed according to (Buday, 1980), which is display about (1393.6m) thick, of consecutive beds of sandstone and claystone. Sandstone is light brownish grey to light olive grey, occasionally reddish brown, firm to hard, fine to coarse grained, thickly bedded, poorly cemented, calcareous, occasionally ripple marked and cross bedded. Claystone is moderately reddish brown to moderately brown, soft to firm, thinly bedded, moderately bedded in places, silty and fractured. The Formation deposited in the Upper Miocene, lagoonal conditions, progressively changed into lacustrine and finally to fluviolacustrine (Buday, 1980). The lower contact of Injana Formation is conformable and gradational with Fat'ha Formation. The upper contact of the Formation is conformable with Mukdadiya Formation (Jassim\& Goff, 2006 and Al- Naqib, 1960).

The study area forms a part of the Zagros Folded Zone which is situated within the physiographic zone called Foothill Zone (in the middle of Hemrin- Makhul subzone) in the unstable shelf of Iraq (Jassim and Goff, 2006) (figure 2). Pulkhana anticline (study area) is one of the important structural elements in Hemrin- Makhul subzone. It is asymmetric long anticline trends (NW_SE). The anticline is overthrust from the NE in the exposed rocks and the most of the SW limb of the anticline is absent beneath the recent deposits. The core of the structure comprises rocks of Lower Fars Formation surrounded by rocks of Upper Fars and Lower Bakhtiary Formations, whereas Upper Bakhtiary Formation forms the slopes of the low hills surrounding the anticline (figure3). These Formations range in age from Middle Miocene to Pliocene (Al- Naqib, 1960).

\section{Materials and Methods}

Field work was carried out through field measurements and observations for about 13 days, lasted from (13/ 12/ $2016)$ to $(25 / 03 / 2017)$. Field work has been taken this time due to the bad lands that almost cover all over the study area, bad weathering conditions, bad security situations and the existence of land bombs (mines).The study was carried out in 10 stations (figure 4) covering the study area. The area of each station was not less than $5 \times 10 \mathrm{~m}$, while the location and distribution of these stations were mainly based on the availability of clear exposure and importance of engineering and structural position. Attitude of the stations has been taken by GPS type Garmin. Topographic map of scale 1:23000 (Drawn by GIS) used as base map. Geologic map of the study area drown by Gis from modulating the geological map of Tuzkhurmatu and surrounding areas (after Sissakian, 1978). At each station discontinuities (fracture) attitude was measured by using compass type Brunton.

Discontinuities spacing, persistence and aperture were measured by using measuring tape of $30 \mathrm{~m}$. Digital camera used for photo taking of discontinuities. Brief lithological description of the exposed Injana Formation has been done at each station following the steps of sedimentary rock description of (Tucker, 1982). The office work of the present study included two steps, first step: analysis of field data by following the technique of (Ramsay and Huber, 1987), which is plotting the poles of discontinuities on the stereographic project (schmidth type) and distinguishing geometrically joint types, sets and systems as well as estimation of stress direction. And second step calculating the average of discontinuities orientation, spacing, aperture, persistence, frequency, roughness, filling and density in the study area.

\section{Discontinuities}

Discontinuity is a general term includes all types of mechanical break or plane of weakness in a rock mass such as joints, bedding planes, fractures, and shear zone that weakened the strength of rock masses (Zhang, 2016). Discontinuities can reduce rock mass strength by providing weakness planes in the rock mass whereas, accumulations of stronger material at discontinuities surfaces such as quartz will increase the rock material strength (Priest and Hudson, 1976; EdyTonnizam et al., 2005; EdyTonnizam et al., 2011). The parameters of discontinuities are geometric properties such as orientation, spacing, persistence, roughness, wall strength, number of sets, aperture, filling, seepage and block size (Anon, 1977; Barton, 1995; Bell, 2007; Zhang, 2016).To evaluate any site, many discontinuity parameters can be use according to the purpose of the study (ISRM, 1978), whereas in the study area (Pulkhana anticline) only eight parameters were used to evaluate the discontinuity of Injana Formation. 


\section{Discontinuities orientation}

Orientation is attitude of a discontinuity in space the two necessary and sufficient conditions for the definition of the orientation of a particular plane are its dip and dip direction (also given as strike and dip). The dip of a particular surface is the maximum angle between the plane containing the surface and the horizontal and is recorded in degrees from $0^{\circ}$ to $90^{\circ}$., and the dip direction or azimuth of this line, measured clockwise from true north (ISRM, 1978; Zhang, 2016; Cruden\& Hu, 1994 and Ramamaurthy, 2008). For example: dip direction/ dip angle $071^{\circ} / 25^{\circ}$ or strike/ dip angle $341^{\circ} / 25^{\circ}$. The average discontinuity orientation readings of Injana Formation were designated in (table1). To detect the geometrical and genetic relationship with the stress in the region, the discontinuity analysis according to the principal tectonic axes was done. Fractures (hko, kol and hkl) were representative in the form of shear fractures and $(\mathrm{ac} \& \mathrm{bc})$ in the form of extension fractures.

The maximum principal stresses were calculated from conjugate (hko acute about a) fractures was between N39- 50.5E.

\section{Discontinuities spacing}

Discontinuities spacing is the vertical distance between adjacent discontinuities (ISRM, 1978; Zhang, 2016) (figure 6b). Discontinuity influence on rock slope stability and block size and shape of rocks, (ISRM, 1978; Goodman and Bray, 1976; Zhang, 2016). The average spacing of all station was measured in the present study and designated in (table 1).

\section{Discontinuities persistence}

Discontinuity persistence is the trace length to its termination in solid rock or other discontinuities, as observed on the surface of exposures (ISRM, 1978; and Zhang, 2016) (figure 6a) and it is one of the most important rock mass parameters because of its direct influence on stability of rocks and block size (Einstein et al., 1983). In the present study, the average of discontinuity persistence was measured in all stations and put in (table 1).

\section{Discontinuities aperture}

Discontinuity aperture is the maximum distance between adjacent rock walls of discontinuities in which the intervening space is filled with air or water (ISRM, 1978, Zhang, 2016) (figure 6a).

Aperture with orientation, filling materials and spacing effects on the hydraulic conductivity of rock mass (Personal communication). The average discontinuity aperture was measured for all stations as shown in (table $1)$.

Table.1 The average readings of discontinuities in the study area

\begin{tabular}{|c|c|c|c|c|c|c|c|}
\hline \multirow{2}{*}{$\begin{array}{l}\stackrel{0}{ٍ} \\
\stackrel{2}{E} \\
\stackrel{0}{0}\end{array}$} & \multirow{2}{*}{ 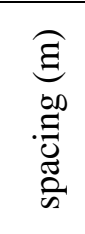 } & \multirow{2}{*}{ 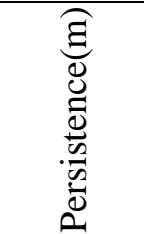 } & \multirow{2}{*}{ 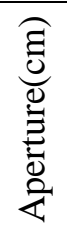 } & \multirow{2}{*}{ 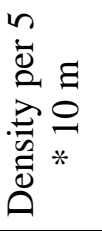 } & \multirow{2}{*}{ 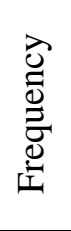 } & \multicolumn{2}{|c|}{ 苐 } \\
\hline & & & & & & $\begin{array}{l}\text { Dip } \\
\text { direction }\end{array}$ & $\begin{array}{l}\text { Dip } \\
\text { angle }\end{array}$ \\
\hline$a b$ & 0.7 & $\begin{array}{c}\text { With } \\
\text { bedding }\end{array}$ & 4 & 3.7 & 41 & 48 & 34 \\
\hline $\mathrm{ac}$ & 0.5 & 3.1 & 4.5 & 2.29 & 37 & 298 & 88 \\
\hline $\mathrm{bc}$ & 0.7 & 5 & 7.5 & 4.9 & 49 & 206 & 57 \\
\hline hko1>a & 0.37 & 5.5 & 6 & 5.1 & 46 & 160 & 70 \\
\hline hko2>a & 0.27 & 4.8 & 8 & 6.7 & 70 & 315 & 83 \\
\hline hko3>b & 0.5 & 4 & 9 & 4.8 & 60 & 199 & 65 \\
\hline hko4>b & 0.21 & 6 & 7 & 5 & 42 & 197 & 62 \\
\hline hol1>a & 0.7 & 1.4 & 3 & 0.45 & 16 & 220 & 55 \\
\hline hol3>c & 0.6 & 1.5 & 5 & 0.57 & 19 & 118 & 25 \\
\hline hol4>c & 0.7 & 1.4 & 3 & 0.5 & 17 & 330 & 27 \\
\hline $\mathrm{hkl}$ & 1.15 & 1.2 & 3 & 0.38 & 16 & 65 & 69 \\
\hline
\end{tabular}


Fig.1 Location and geological map of the study area

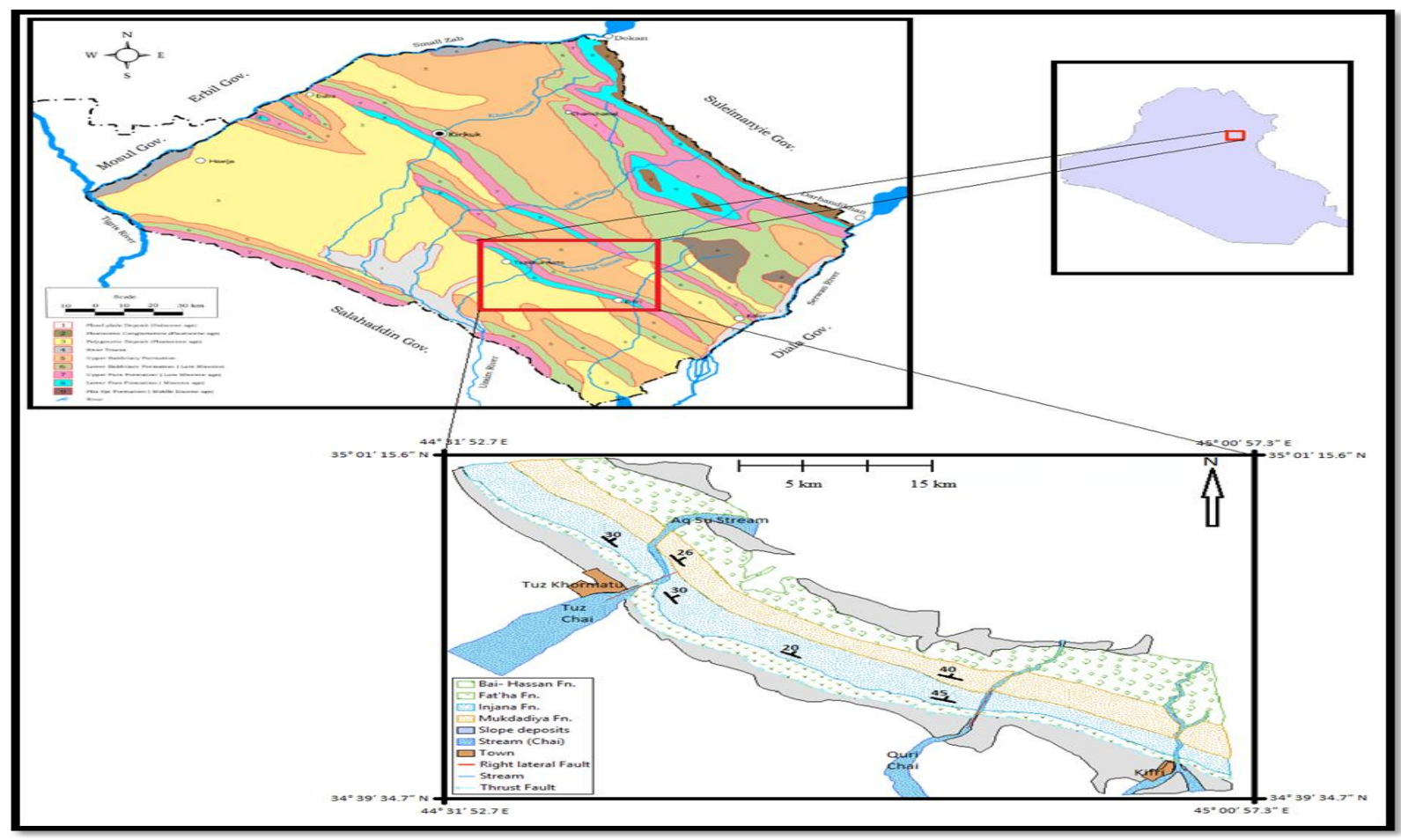

Fig.2 Tectonic map of Iraq (after Al- Kadhimi et al., 1996)

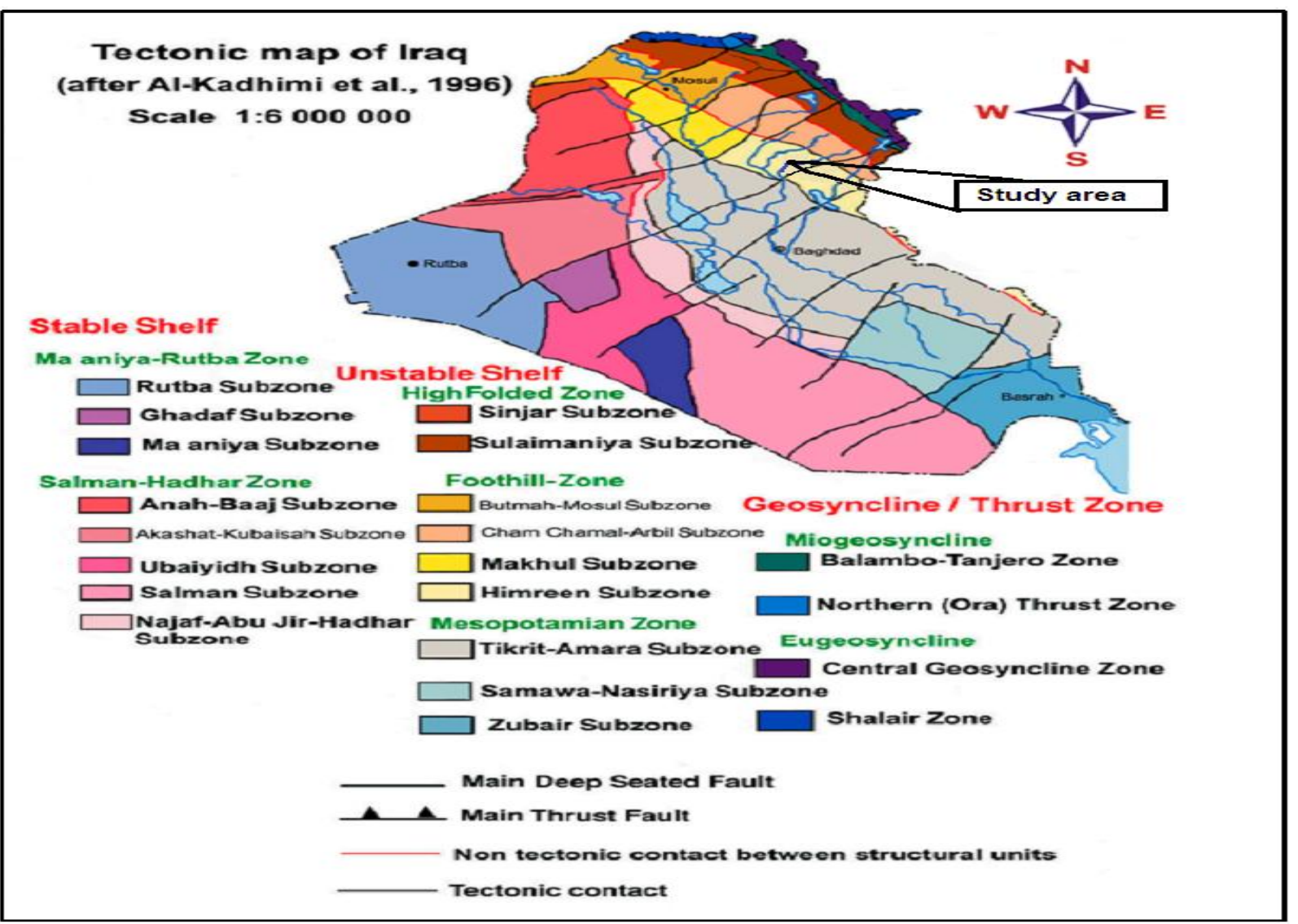


Fig.3 Generalized stratigraphic column of the exposed formations in the study area

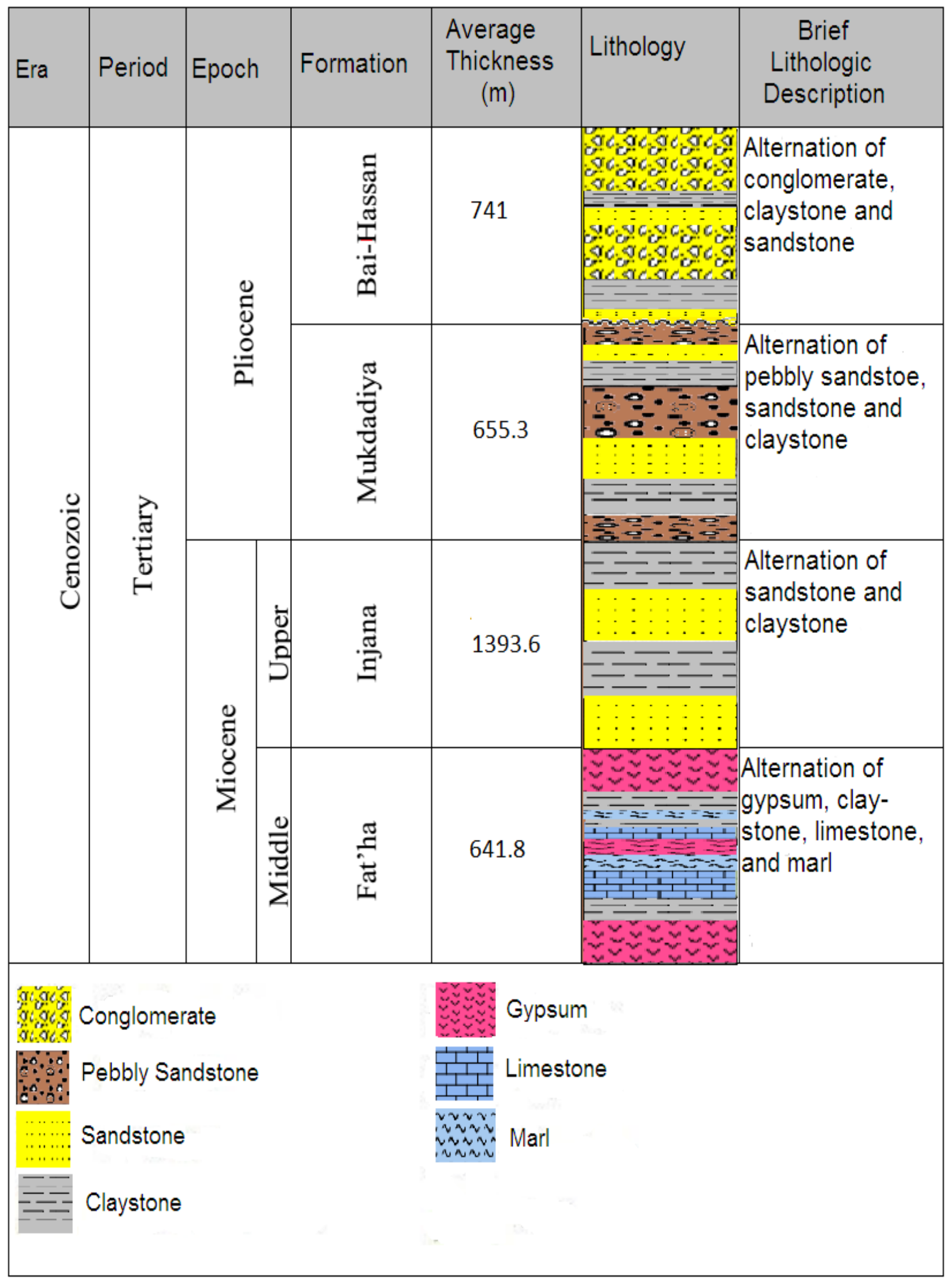


Fig.4 Typical roughness profile and suggested nomenclature. The length of each profile is in the range of 1 to 10 meters. The vertical and horizontal scale are equal (after ISRM, 1978)

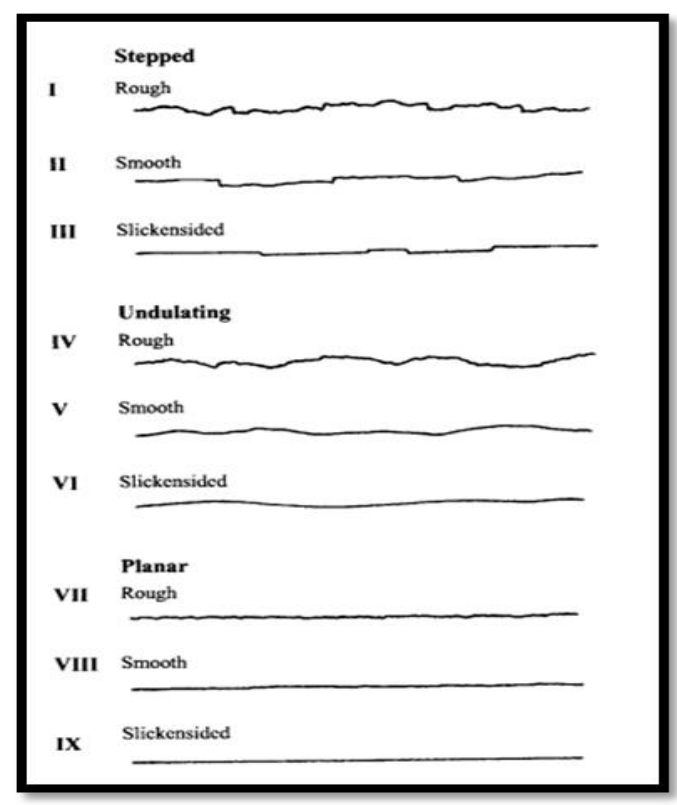

Fig.5 Discontinuity (fracture) analysis of the study area by using Dips ver.1.5

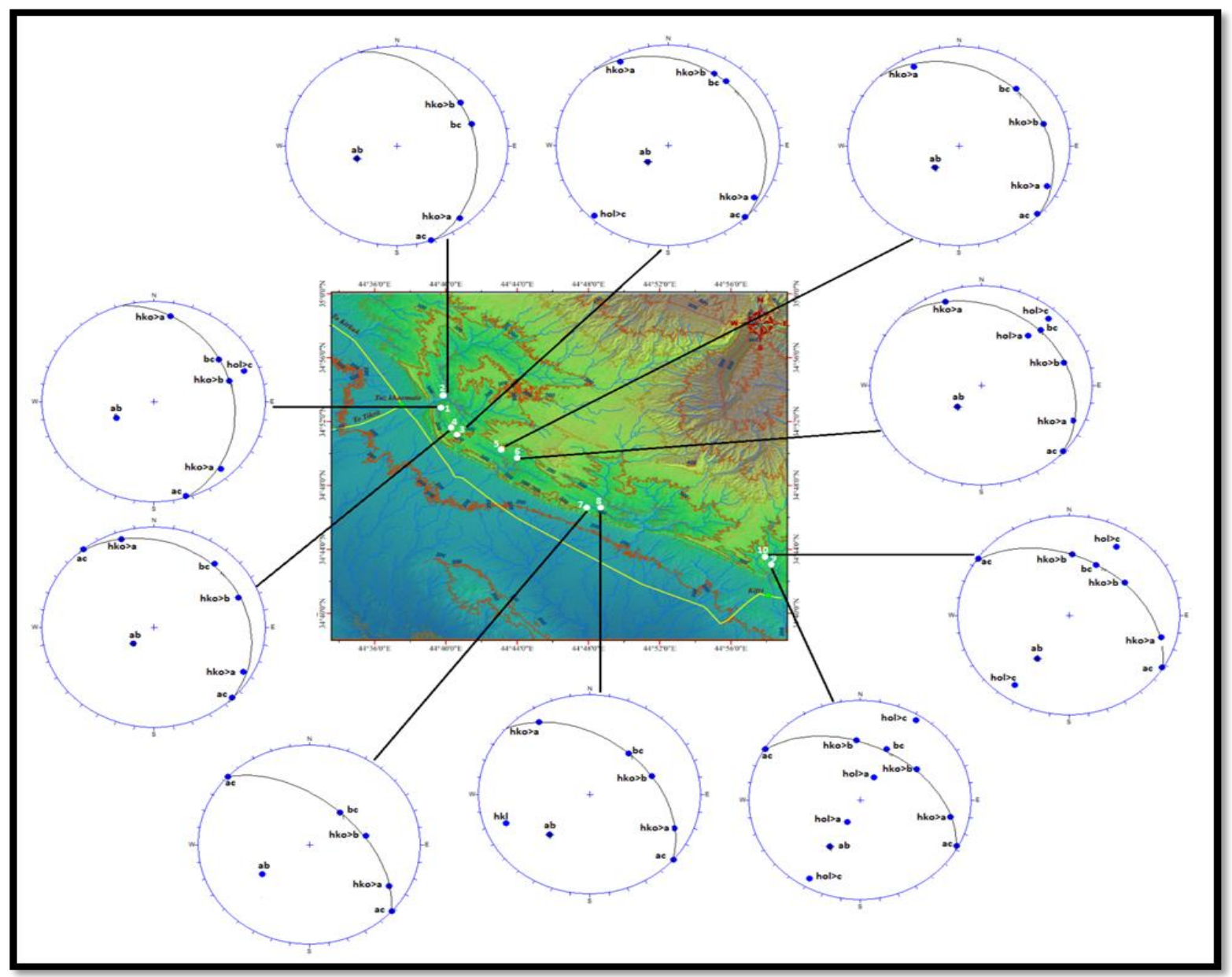


Fig.6 a) shows persistence and aperture, b) shows filling material and spacing of discontinuities in the study area

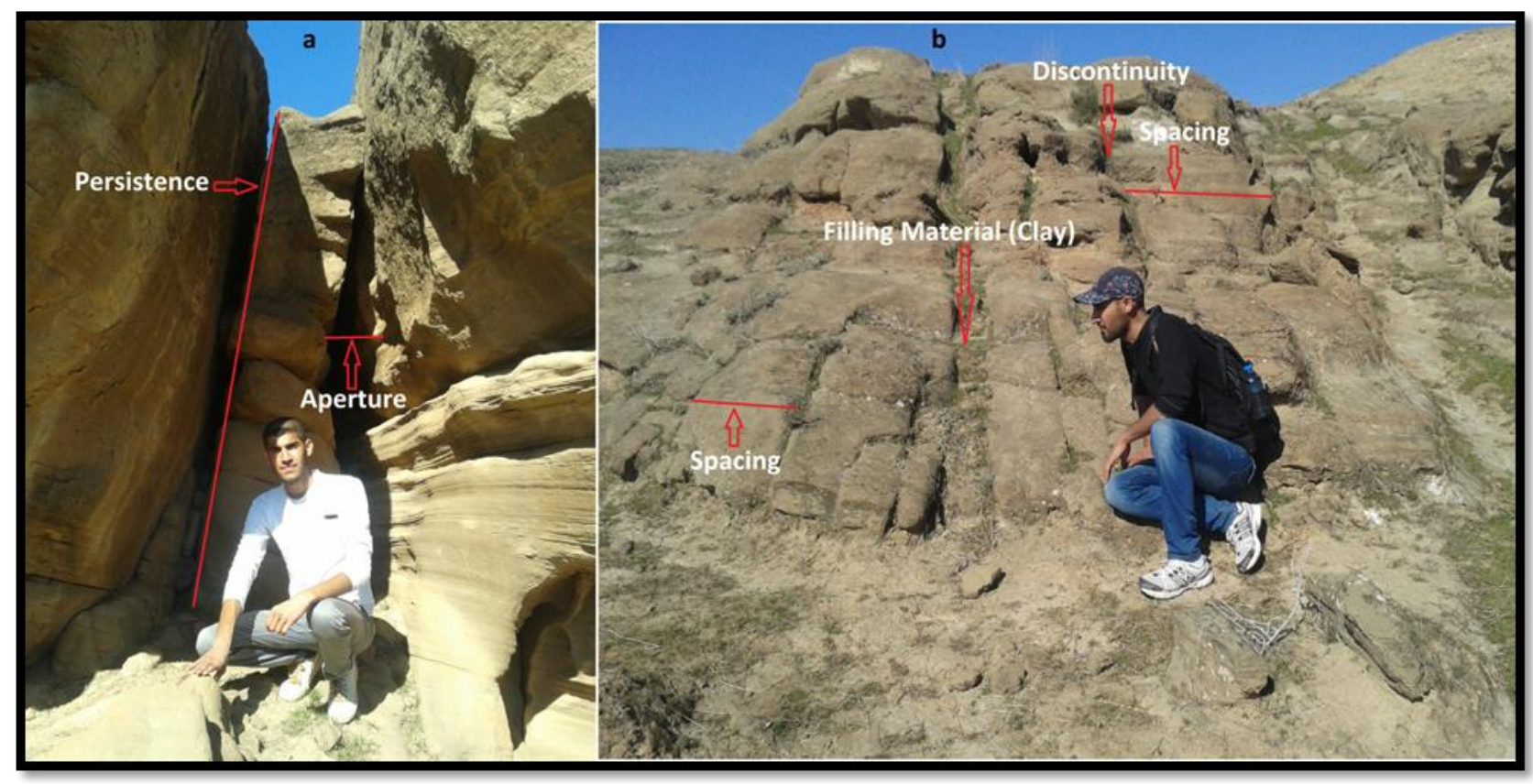

\section{Discontinuities Roughness}

Roughness is a term used for description of immanent discontinuity surface (ISRM, 1978). Roughness plays an important role in contribute to shear strength (especially when the features are undisplaced and interlocked such as unfilled joints) and in understanding mechanical behavior and permeability characteristics of rock mass (Barton, 1973) and (Barton \&Choubey, 1977). The significance of roughness decrease with the increasing of aperture and filling thickness. By following the roughness profile (figure 4), the discontinuity roughness in the study area ranges from rough planar to smooth undulating.

\section{Discontinuities filling}

Filling is a term refers to all materials existingbetween the discontinuity walls (ISRM, 1978) (figure 6b). These materials like calcite, chlorite, clay, silt, fault gourge, breccia, quartz and pyrite (Zhang, 2016). Filling material have a major influence on the shear strength of discontinuity. With the exception of discontinuities filled with strong vein materials (calcite, quartz, pyrite), filled discontinuities generally have lower shear strengths than comparable clean, closed discontinuities. In the study area discontinuities either open or filled with clay except in station seven were some discontinuities filled with calcareous materials.

\section{Discontinuities density}

It is the cumulative trace length of discontinuities in a given area regardless of their orientation (Hoek and Bray, 1981; Davis and Reynolds, 1996; Zhang, 2016).

In the present study, density was measured within an area of $5 \times 10 \mathrm{~m}$ for all field station using the following equation:

$$
d=\frac{1}{A} \times \sum_{i=1}^{N} L i
$$

Where:

$\mathrm{d}=$ discontinuity density

$A=$ area of discontinuity density measurement $\left(\mathrm{m}^{2}\right)$

$\mathrm{i}=$ discontinuity number

$\mathrm{N}=$ whole number of discontinuities within $\mathrm{A}$

$\mathrm{L}=$ discontinuity length

Discontinuity density was measured in all stations (table 1 ) and it showed wide variation.

In the study area, density used for evaluation of porosity and permeability of the exposed rocks. 


\section{Discontinuity frequency}

Discontinuity frequency is described as a number of discontinuities that are observed or predicated to exist in a unit volume. Discontinuity frequency is one of the principal measures of the degree of fracturing in the rock mass (Priest, 2012). In the study area, the average of discontinuity frequency is measured and put in (table 1).

The following conclusions of general interest have been made:

Most of discontinuities in the study area have high dip angle; therefore, they influence as a back release surfaces, lateral release surfaces and composite back release surfaces.

Block size in the study area ranges from very small blocks $(60-200 \mathrm{~mm})$ to large blocks $(200-2 \mathrm{~m})$, occasionally very large blocks $(>2 \mathrm{~m})$, and block shape ranges from rhombohedral to equidimensional blocks.

Determination of discontinuity orientation, persistence, roughness and filling reveal that there is a potential hazard on the study area due to their direct influence to the stability of rocks.

The principal stress direction that led to form fractures in the study area is directed $\mathrm{N} 39-50.5 \mathrm{E}$ which is compatible with the regional stress that result from the collision of Arabian plate with Iranian.

Most common fracture types in the study area is compressional which is represented in the form of shear fractures (hko, hol and hkl) and there might be some local stress represented in the form of tension fractures (ac and bc).

Fracture analysis reveal that both shear and extension fractures are common in the study area.

\section{References}

Al-Kadhimi, J.M.A., Sissakian, V.K., Sattar, A.F. and Deikran, D.B. (1996) Tectonic Map of Iraq. 2nd Edition, Geo Survey, Baghdad, Iraq.

Al-Naqib K. M., 1960. Geology of The Southern Part of Kirkuk Liwa, Tech. Publ., Iraq Petrol. Co. Ltd, 50p.(In Arabic).

Anon, 1977. The Description of Rock Masses for Engineering Purposes. Working Party Report of the
Engineering Group of the Geology Society of London. Quarterly Journal of Engineering Geology, 10, 355- 388.

Barton, N., \& Choubey, V. 1977. The shear strength of rock joints in theory and practice. Rock Mechanics and Rock Engineering, 10(1), 1-54.

Barton, N., 1973. Review of a new shear-strength criterion for rock joints. Engineering geology, 7(4), 287-332.

Barton, N., 1995. Permanent Support for Tunnels using NMT- Special Lecture Proc. Symp. Of KRMS (Korea Rock Mechanics Society) and KSEG (Korea Society of Engineering Geology).

Bell, F. G., 2007. Basic environmental and engineering geology (No. 631.47 B433). Whittles Publishing.

Bellen, R.C., Dunington, H.V., Wetzal, R. and Morton, D.M. 1959. Lexique Stratigraphy International, Asie, Fascicle.10a, Iraq. Center National de la RecherghesScientifique, Paris, and 333 p.

Billings, M., 1972. Structural Geology, Third Edition, Prentice-Hall Inc. 606p.

Buday, T., 1980. The Regional Geology of Iraq, Vol 1: Stratigraphy and Paleogeography. Publications of Geological Survey of Iraq, Baghdad, 445 p.

Cruden, D.M. and Hu, X.Q. 1994. Toppling on Underdip Slope in the Higwood Pass Alberta, Canda. Quarterly Journal of Engineering Geology, 27, 5768.

Davis, G.H., and Reynolds S.J. 1996. Structural Geology of Rock and Regions. John Wiley and Sons Inc., New York, $287 \mathrm{p}$.

EdyTonnizam Mohamad, KhairulAnuarKassim and Ibrahim Komoo 2005. To Rip or To Blast: An Overview of Existing Excavation Assessment. Brunei International Conference on Engineering and Technology (BICET 2005): 27-36.

EdyTonnizam Mohamad, Seyed Vahid Alavi Nezhad Khaili Abad \& Rosli Saad 2011. Challenges of Excavation by Ripping Works in Weathered Sedimentary Zone, Electronic Journal of Geotechnical Engineering, Bund 16 O, pp 13371350, ISSN 1089-3032

Einstein, H. H., Veneziano, D., Baecher, G. B., \& O'reilly, K. J. 1983. The effect of discontinuity persistence on rock slope stability. International journal of rock mechanics and mining sciences \&geomechanics abstracts (Vol. 20, No. 5, pp. 227236).

Goodman, R. E., 1980. Introduction to Rock Mechanics. Wiley. New York.

Goodman, R. E., 1989. Introduction to rock mechanics (Vol. 2, p. 576). New York: Wiley. 
Goodman, R.E., and Bray. J.W. 1976. Toppling of Rock Slopes. Proceedings of the Specialty Conference on Rock Engineering for Foundations and Slopes, 2, 201-234.

Henning, P.H., Olson, J.E. and Thompson, L.B. 2001. Combining Outcrop Data and Three Dimensional Structure Models to Characterize Fractured Reservoirs (and Example from Wyoming). American Association of Petroleum Geologists AAPG Bulletin, 84, 830-849.

Hoek, H., and Bray, J.W. 1981. Rock Slope Engineering. 3rd Edition, Institution of Mining and Metallurgy, London, $358 \mathrm{p}$.

ISRM (International Society for Rock Mechanics) 1978. Suggested Methods for the Quantitative Description of Discontinuities in Rock Masses. International Journal of Rock Mechanics and Mining Sciences \&Geomechanics Abstracts, 15, 319-368.

Jassim, S.Z., and Goff, J.C. 2006. Geology of Iraq. Czechrepublic, Brno, $341 \mathrm{p}$.

Plummer, C.C., D. Mc Geary, D. H. Carson, 2003. Physical Geology.Mc Geary- Hill, New York, 9th. Edition, 574p.

Pollard, D. D., \& Aydin, A. 1988. Progress in understanding jointing over the past century. Geological Society of America Bulletin, 100(8), 1181-1204.
Priest, S. D., 2012. Discontinuity analysis for rock engineering. Springer Science \& Business Media.

Priest, S.D., and Hudson, J.A., 1976. Discontinuity spacings in rock: International Journal of Rock Mechanics, Mineral Science \&Geomechanics Abstract, v. 13: 135-148.

Ramamaurthy, T., 2008. Engineering in Rocks for Slopes. Foundation and Tunnels, New Delhi, 357 p.

Ramsay, J. G. and Huber, M. I., (1987), Folds and fractures: The techniques of modern structural geology, V.2, New York, Academic Press, 700p.

Sens, Z., and Kazi, A. 1984. Discontinuities Spacing and RQD Estimates from Finite Length Scanline. International Journal of Rock Mechanics and Mining Sciences \&Geomechanics Abstracts, 3, 203212.

Shamaran Petroleum Crop. 2010. Exploration and Development in Kurdistan.

Sissakian, V. K., 1978. Report on the Regional Geological Survey of Tuzkhurmatu, Kefri, and Kalar area. GEOSURVE, Internal report, No.902, part I. Baghdad.

Tucker, M. E., 1982. The field description of sedimentary rocks (No. 552.5 TUC).

Twiss, R. J., and Moores, E.M., 2007. Structural geology, W.H. Freeman and Company, New York, $742 \mathrm{p}$.

Zhang, L., 2016. Engineering properties of rocks. Butterworth-Heinemann.

\section{How to cite this article:}

Zakariya Qasm Jadaa and Burkan saeed Othman. 2017. Discontinuities Study in Injana Formation in the Northeastern Limb of Pulkhana Anticline/ Northeast Iraq. Int.J.Curr.Res.Aca.Rev. 5(8), 51-59.

doi: https://doi.org/10.20546/ijcrar.2017.508.008 